\title{
Supervision in the Master of Applied Indigenous Knowledge programme at Te Wānanga o Aotearoa in Māngere
}

The purpose of this paper is to explain briefly the voluntary roles of the Indigenous Master Practitioner (IMP) and tuakana/supervisor in the Master of Applied Indigenous Knowledge (MAIK) programme at Te Wānanga o Aotearoa in Māngere. This paper will concisely explain the MAIK programme and the roles of IMP and tuakana/supervisor. This paper will present a model of supervision that was used by the author to supervise ten students successfully; it is intended that IMPs and tuakana/supervisors might consult the model if they do not already have an approach of their own.

MAIK is a two-year programme that acknowledges the expertise of Indigenous practitioners in particular fields of knowledge and leads them through the process of writing a 15,000-20,000-word exegesis and realising a research-based project that meaningfully contributes to the development of their Indigenous communities (Rangiwai et al., 2020b). In Year 1, lecturers steer students through the completion of assessments (Rangiwai et al., 2020b). However, in Year 2, students are supervised by voluntary experts that they choose themselves (Rangiwai et al., 2020b). In Year 2, students must approach and select a voluntary IMP (Rangiwai et al., 2020b). This person should be an expert in a particular field that relates closely to the field of knowledge and practice of the student; the IMP 
supervises the project (Rangiwai et al., 2020b). In Year 2, supported by MAIK lecturers, students are required to interview participants, and analyse the data, in order to inform and shape the planning of a community project.

Students must also approach and select a voluntary tuakana/supervisor-a person with a doctorate-who oversees the exegesis (Rangiwai et al., 2020b). The word exegesis comes from the Greek, to interpret and lead, and was first applied to scriptural analysis and later extended to refer to an explanation or expository discourse (Kroll, 2004). In the MAIK programme, the exegesis refers to an explanatory or expository text that documents the inception and implementation of the project, demonstrates connections between theory and practice, describes profound learning experiences through reflection and analysis and identifies areas for future research (Rangiwai et al., 2020b). In preparing students for their project work, we ask them to ask themselves the following questions:

- What is the purpose of the project? What do I hope to achieve?

- How will my project fit into my cultural context?

- How will my cultural and personal values, beliefs, and ideas influence my project?

- What works of other practitioners, past and present, will influence my project?

- What do I see as the strengths and weaknesses of my project?

- What frustrations do I experience in achieving my goals for the project?

- What limitations are inherent in the process, both technical and creative?

- Where should the project be implemented (the physical location), and why? 
- How does my work make an original contribution to the field? (adapted from University of Otago, n.d.).

The following image is a map of the MAIK programme. The He Waka Hiringa Map is a guide for students to visualise and conceptualise their master's journey over Year 1 (orange) and Year 2 (green) (Rangiwai et al., 2020a). While the map does not include dates, the various sections of the map coincide with 5-day teaching intensives scheduled throughout 2020 and 2021 (Rangiwai et al., 2020a).

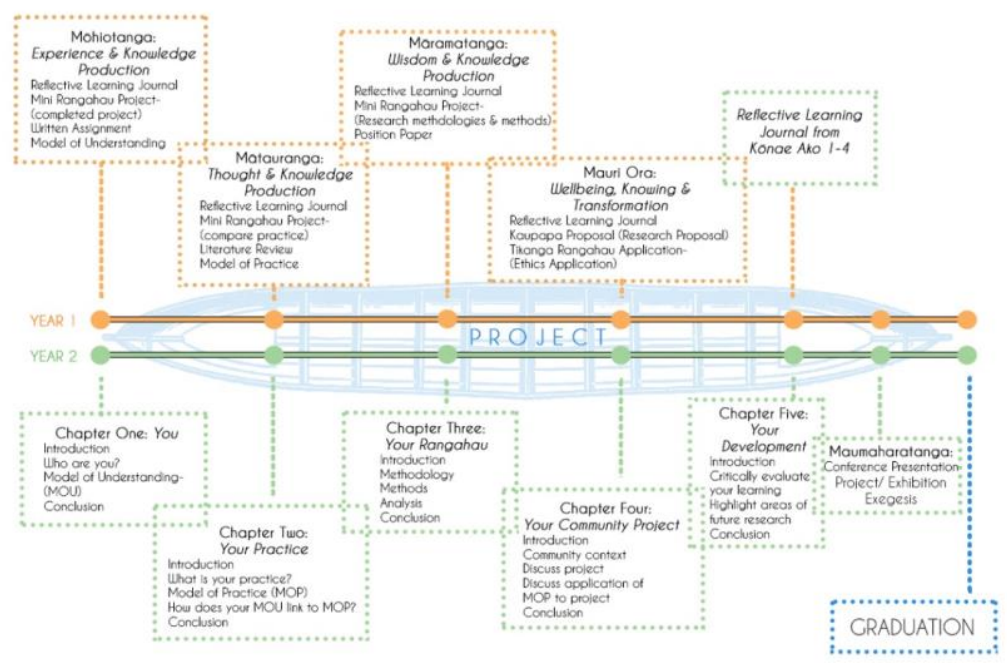

Figure 1: He Waka Hiringa Map (Rangiwai et al., 2020a, p. 6). ${ }^{1}$

Each paper-Mōhiotanga, Mātauranga, Māramatanga, Mauri Ora-builds on and flows into the

${ }^{1}$ Dr Benita Simati-Kumar Chand designed and created this model. 
next - implied by the intersecting boxes (Rangiwai et al., 2020a). Also, each paper from Year 1 informs the final paper-Maumaharatanga-made up of a project, an exegesis, and an on-campus conference presentation (Rangiwai et al., 2020a). Appropriately, the main written assessment for each paper may form the foundation of draft exegesis chapters one through four, while the reflective learning journal component directly informs chapter five (Rangiwai et al., 2020a). The waka signifies the project which is pivotal to the programme and is symbolised in such a way that it overlies both years; the project should be a considerable contribution to a field of Indigenous knowledge and practice (Rangiwai et al., 2020a). Not only does the waka represent the project, but students should also consider that their respective communities join them on the journey; students, therefore, are responsible for and accountable to their communities in extensive and profound ways (Rangiwai et al., 2020a). Notably, students are also required to publicly exhibit their project work, supported by MAIK staff, in a way that is accessible to the community (Rangiwai et al., 2020a).

The following table is intended to demonstrate the integration of the project and exegesis and the roles of IMP and tuakana/supervisor. 


\begin{tabular}{|c|c|}
\hline Project & $\begin{array}{l}\text { Exegesis } \\
\text { (the write-up) }\end{array}$ \\
\hline $\begin{array}{ll}\text { Supervised by IMP } \\
\text { - } \\
\text { - } & \text { Pxpert in field } \\
& \text { knowen experience \& } \\
\text { - } & \text { Supervises } \\
& \text { implementation the } \\
& \text { the project } \\
\text { - } & \text { Marks final project }\end{array}$ & $\begin{array}{l}\text { Supervised } \\
\text { tuakana/supervisor } \\
\text { - Holds a doctorate } \\
\text { (in any field) } \\
\text { - Assists students } \\
\text { with concepts \& } \\
\text { writing (lecturers } \\
\text { check) } \\
\text { - Marks exegesis }\end{array}$ \\
\hline $\begin{array}{l}\text { Purpose: To make a } \\
\text { significant contribution to a } \\
\text { field of Indigenous } \\
\text { knowledge/practice }\end{array}$ & $\begin{array}{l}\text { Purpose: To explain the } \\
\text { inception \& implementation } \\
\text { of the project, demonstrate } \\
\text { connections between theory } \\
\& \text { practice, describe } \\
\text { profound learning } \\
\text { experiences, \& identify areas } \\
\text { for future research }\end{array}$ \\
\hline $\begin{array}{l}\text { Project pre-planning by } \\
\text { student }\end{array}$ & $\begin{array}{l}\text { Supervises exegesis } \\
\text { (chapters checked by } \\
\text { lecturers first) }\end{array}$ \\
\hline \multirow{4}{*}{$\begin{array}{l}\text { Research (supported by } \\
\text { lecturers) } \\
\text { - Interviews } \\
\text { - Transcription } \\
\text { - Data analysis } \\
\text { - Data to inform } \\
\text { project }\end{array}$} & Chapter One: Introduction \\
\hline & Chapter Two: Practice \\
\hline & $\begin{array}{l}\text { Chapter Three: } \\
\text { Rangahau/research } \\
\text { (to inform project) }\end{array}$ \\
\hline & $\begin{array}{l}\text { Chapter Four: Project } \\
\text { (write-up) }\end{array}$ \\
\hline $\begin{array}{l}\text { Project planning } \\
\text { implementation- } \\
\text { supervised by IMP }\end{array}$ & Chapter Five: Conclusion \\
\hline IMP marks project & $\begin{array}{l}\text { Tuakana/supervisor } \\
\text { marks exegesis }\end{array}$ \\
\hline \multicolumn{2}{|c|}{ Presentation } \\
\hline & \\
\hline
\end{tabular}

Figure 2: Project \& Exegesis table 


\section{He Raranga Tangata ${ }^{2}$-a model for supervision}

In the context of the MAIK programme in Māngere, the term "supervision" refers to the coaching, mentoring, and guidance provided to the student by the tuakana/supervisor who voluntarily supervises the exegesis, and the IMP who voluntarily supervises the project. The term "supervisor" in the context of the He Raranga Tangata model refers to both the IMP and tuakana/supervisor. The He Raranga Tangata model may be used to inform supervision of both the project and the exegesis and so may be useful to both tuakana/supervisors and IMPs. Rangiwai et al. (2019) created the He Raranga Tangata model based on their experience of supervision as supervisor and students. In 2019, Byron Rangiwai supervised the exegeses of the Reverend Mahaki Albert (Māori), Tania Bell (Māori), William Cuthers (Cook Islands Māori/Māori), Fritz Filisi (Samoan), Vania Hotereni (Māori), Celia Lambert (Māori), Rosalie Leuluai (Māori), Latoia Sasa-Tepania (Samoan/Māori), and Daena Walker (Māori) (Rangiwai et al., 2019). Byron also supervised Abann Yor's (Sudanese) project (Rangiwai et al., 2019). The He Raranga Tangata model is made up of four principles:

1) Whakateretanga (Navigation)-drive and direction, motivation, communication, productivity, availability

2) Manaakitanga (Hospitality)—aroha, support, patience, honesty, encouragement

3) Kotahitanga (Unity)-intellectual and social collectivity, group strength and support

4) Pūkengatanga (Expertise)-teaching, modelling, knowledge, critical and constructive feedback, opportunities, quality, transformation (Rangiwai et al., 2019, p. 8).

2 The name for this model was given by the Reverend Mahaki Albert in 2019. 
In the poutama-based model that follows, Manaakitanga, Kotahitanga and Pūkengatanga are connected through Whakateretanga-the impetus behind what was actioned as supervisor and student (Rangiwai et al., 2019). Indeed, "Whakateretanga is the drive that pushed us to achieve excellence and expertise in our respective fields of knowledge" (Rangiwai et al., 2019, p. 8).

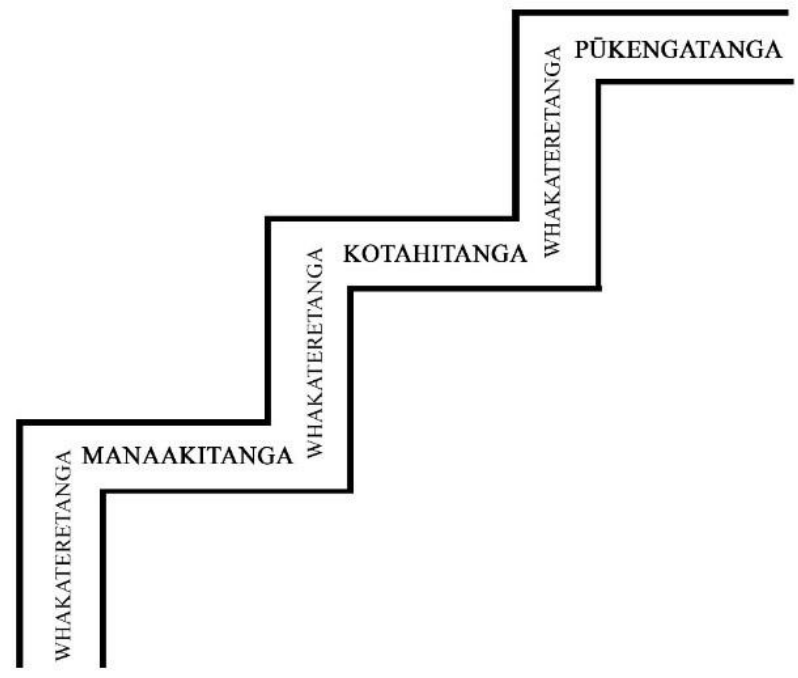

Figure 3: He Raranga Tangata model (p. 9). ${ }^{3}$

${ }^{3}$ Dr Benita Simati-Kumar Chand made this model. 
The following explanations of the principles of the model have been adapted from Rangiwai et al. (2019, pp. 9-11):

\section{Whakateretanga (Navigation)}

- Drive and direction: Supervisor ${ }^{4}$ drives and directs the student to achieve agreed outcomes

- Motivation: Supervisor motivates the student to achieve agreed writing/project goals

- Communication: Supervisor and student communicate regularly

- Productivity: Supervisor and student engage in ways that contribute productively to the master's work

- Availability: Supervisor maintains availability

\section{Manaakitanga (Hospitality)}

- Aroha: Supervisor demonstrates love, compassion and concern for the student

- Support: Supervisor provides holistic support

- Patience: Supervisor demonstrates patience

- Honesty: Supervisor and student are honest with one another

- Encouragement: Supervisor encourages student

\section{Kotahitanga (Unity)}

- Intellectual and social collectivity: Supervisor and student to come together and share

- Group strength and support: Supervisor and student to strengthen, support, and learn from one another

\section{Pūkengatanga (Expertise)}

- Teaching: Supervisor provides excellent teaching/mentoring to student

- Modelling: Supervisor models expectations

4 The term "supervisor" may refer to either the IMP or tuakana/supervisor in the context of the He Raranga Tangata model. 
- Knowledge: Supervisor imparts and coconstructs knowledge with student

- Critical and constructive feedback: Supervisor provides critical and constructive feedback to the student as a means of promoting critical reflection and improvement

- Opportunities: Supervisor highlights suitable opportunities for student, such as publishing or community activities

- Quality: Supervisor provides the student with a high-quality mentoring experience

- Transformation: Supervisor provides opportunities for positive transformation; the student takes advantage of those opportunities and works to transform themselves through their master's work in ways that benefit their whānau, the communities that they serve, and themselves.

He Raranga Tangata is but one model that could be used by supervisors who volunteer their time to benefit students in the MAIK programme. Of course, supervisors may well have their own style and approach to supervision.

This paper has explained the MAIK programme and the roles of the IMP and tuakana/supervisors. This article has also presented a model for supervision that might be useful to those who are new to supervision. While the roles of IMP and tuakana/supervisor are voluntary, the programme does offer a very humble koha to those who chose to contribute. Students are also asked to reciprocate in culturally appropriate ways. The roles of IMP and tuakana/supervisor are integral to the continuation of the MAIK programme but most importantly, to the success of the students and the progression of their respective communities. As an example of the transformation that is possible through the MAIK programme, the following image is a book published by Abann Yor, who completed the requirements for the MAIK programme in 2019. The book 
is based on his master's project and will contribute significantly to the development of his community.

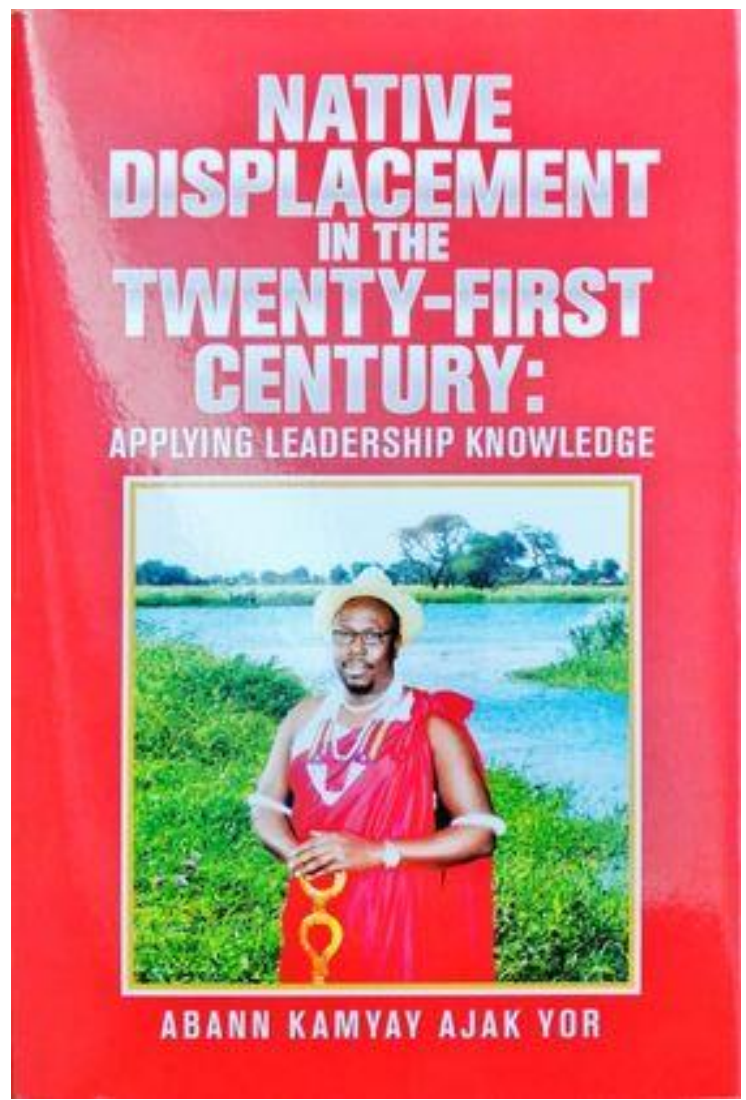

Figure 4: Book cover for Abann Yor's (2020) book 


\section{References}

Kroll, J. (2004). The exegesis and the gentle reader/writer. Text Journal, Special Issue(3). http://www.textjournal.com.au/speciss/issue3/kr oll.htm

Rangiwai, B., Albert, M., Bell, T., Cuthers, W., Filisi, F., Hoterini, V., Lambert, C., Leuluai, R., Sasa-Tepania, L., Walker, D. \& Yor, A. (2019). He Raranga Tangata: A Māori and Indigenous master's research supervision model derived from our experiences of the Master of Applied Indigenous Knowledge programme at Te Wānanga o Aotearoa in Māngere in 2019. Te Kaharoa: The eJournal on Indigenous Pacific Issues, 12(1), $1-13$. https://www.tekaharoa.com/index.php/tekaharoa /article/view/283

Rangiwai, B., Simati-Kumar, B., \& Mataroa, R. (2020a). The He Waka Hiringa Map 2020-2021: Using He Raranga Tangata to support the implementation of the He Waka Hiringa Map in the Master of Applied Indigenous Knowledge programme at Te Wānanga o Aotearoa in Māngere. Te Kaharoa: The eJournal on Indigenous Pacific Issues, 15(1), 1-12. https://www.tekaharoa.com/index.php/tekaharoa /article/view/294

Rangiwai, B., Simati-Kumar Chand, B., \& Mataroa, R. (2020b). The impacts of COVID-19 on the 2020 cohort of the Master of Applied Indigenous Knowledge programme at Te Wānanga o Aotearoa in Māngere. Te Kaharoa: The eJournal on Indigenous Pacific Issues, 15(1), 1-21. https://doi.org/10.24135/tekaharoa.v15i1.301

University of Otago. (n.d.). Writing an exegesis. https://www.otago.ac.nz/hedc/otago615372.pdf

Yor, A. K. A. (2020). Native displacement in the twentyfirst century: Applying leadership knowledge. Xlibris. 